\title{
Plastochron estimate in grapevine 'Marselan' and 'Tannat' cultivars
}

\section{Estimativa do plastocrono em cultivares de videira 'Marselan' e 'Tannat'}

\author{
André Ricardo ZEIST ${ }^{1}$; Cleber Maus ALBERTO²; Tiago Camponogara TOMAZETTI ${ }^{3}$; Márcia Denise \\ ROSSAROLLA ${ }^{3}$; Clevison Luiz GIACOBBO ${ }^{4}$; Leocir José WELTER ${ }^{5}$
}

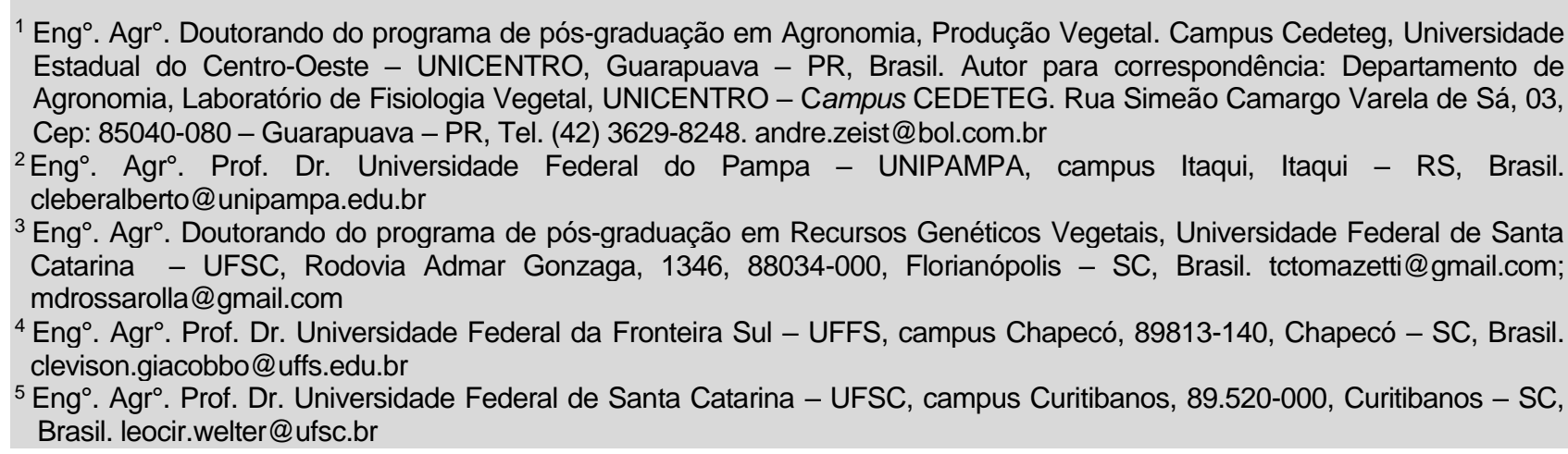

Recebido em: 03-05-2014; Aceito em: 21-07-2016

\begin{abstract}
Plastochron safe estimates contribute for modeling improvement of grapevine development and allow identifying the phenological behavior of culture, to check the adjustment, to set more appropriate management practices and to assist in agricultural zoning culture. Thus, the aim of this study was to estimate the plastochron in Marselan and Tannat grapevine cultivars in the region of the Border West of Rio Grande do Sul. The experiment was conducted in grapevine orchard with Marselan and Tannat cultivars in the municipality of Itaqui-RS in 2010, between September and December. The plastochron was estimated by the inverse of slope of the linear regression between the number of visible nodes by branches and thermal time (base temperature of $10^{\circ} \mathrm{C}$ ). For Marselan and Tannat grapevine cultivars can be used plastochron value of approximately $56.25 \stackrel{\circ}{\circ}$ day node ${ }^{-1}$.
\end{abstract}

Additional keywords: fruitfarming; node emission; Vitis vinifera.

\begin{abstract}
Resumo
Estimativas seguras de plastocrono contribuem para o aprimoramento da modelagem do desenvolvimento da videira e permitem identificar o comportamento fenológico da cultura, verificar a adaptação, definir práticas de manejo mais adequadas e auxiliar no zoneamento agrícola da cultura. Assim, o objetivo com este estudo foi estimar o plastocrono nas cultivares de videira Marselan e Tannat na região da Fronteira Oeste do Rio Grande do Sul. O experimento foi conduzido em pomar de videira com as cultivares Marselan e Tannat, no município de Itaqui-RS, no ano de 2010, entre os meses de setembro e dezembro. O plastocrono foi estimado pelo inverso do coeficiente angular da regressão linear entre número de nós visíveis por sarmento e a soma térmica (temperatura-base de $10^{\circ} \mathrm{C}$ ). Para as cultivares de videira Marselan e Tannat, pode ser utilizado valor de plastocrono de aproximadamente $56,25 \stackrel{\circ}{\mathrm{C}}$ dia nó-1.
\end{abstract}

Palavras-chave adicionais: emissão de nós; fruticultura; Vitis vinifera.

\section{Introduction}

According to FAO (2014), in 2011 Brazil had a production of $1,542,068$ tons of grape, with harvested area of 84,338 hectares and productivity around $182,843 \mathrm{~kg} \mathrm{ha}^{-1}$. Rio Grande do Sul was responsible for about $61.4 \%$ of national production (IBGE, 2014). The highest proportion of grapes harvested in the world is used for the production of wine, its use is related to factors such tradition and even religion (Muccillo et al., 2014).

Currently, grapevine cultivation in the West border of Rio Grande do Sul has been expanding and stands out for the production of fine quality wines. However, being a region where the culture is recently being introduced, there is a need to evaluate the phenolical behavior of local soil and climate conditions, in order to improve the technological management of vineyards. The index determination is crucial as thermal requirement, allowing producers the possibility to estimate the occurrence dates of phenological events during the crop development cycle (Silva et al., 2006; Brixner et al., 2010; Pereira et al. 2010). The estimate of occurrence dates of development stages of a particular plant species by developing models is an important tool that assists on 
decision-making regarding the management to be used in culture (Pereira et al., 2010).

A more realistic time measurement from the biological point of view is the thermal time, with unit on ${ }^{\circ} \mathrm{C}$ day (Streck et al., 2008; Fagundes et al., 2008).There is a close relationship between temperature and vegetative growth, interfering temperature on factors such as the growth speed and differentiation of organs. The production of great quality plants is affected by radiant energy (commonly referred as light) and temperature (thermal energy) where thermal energy is the main environmental factor that promotes vegetative development (Liu \& Heins, 2002). Thermal time calculation models are considered simple and easy to use, and only use the inferior basal temperature of culture and maximum and minimum daily air temperatures (Pereira et al., 2010).

The number of nodes (NN) in vine branches can be estimated by plastochron $\left({ }^{\circ} \mathrm{C}\right.$ day node $\left.{ }^{-1}\right)$, whose definition is the time interval $\left({ }^{\circ} \mathrm{C}\right)$ required between the appearance of successive nodes on the stem (Baker \& Reddy, 2001; Streck et al., 2005; Toebe et al., 2010; Lucas et al., 2012) or, as in the case of grapevine, in each branches.

Although currently there are no information on plastochron in grapevine, there are studies plastochron estimate in several plant species such as hybrid muskmelon HY-MARK transplanted at different times in plastic greenhouses (Streck et al., 2005) in soybean cultivars recommended for cultivation in Southern Brazil (Streck et al., 2008), in crambe at two sowing times in the development of sub - periods (Toebe et al., 2010), and on other several vegetables, as watermelon (Lucas et al., 2012), yellow calendula (Fagundes et al., 2008), in common bean (Heldwein et al., 2010) and in cotton (Pereira et al., 2010).

Plastochron safe estimatesto contribute for modeling improvement of vine development and allows to identify the phenological behavior of culture, to check the adjustment, to set more appropriate management practices and to assist in agricultural zoning culture. Thus, the objective of this study was to estimate the plastochron in grapevine cultivars Marselan and Tannat in the West Border of Rio Grande do Sul.

\section{Material and methods}

The experiment was conducted in grapevine orchard with Marselan and Tannat cultivars in the municipality of Itaqui-RS in 2010, between September to December. The property is located on the West border of the state of Rio Grande do Sul (latitude: $29^{\circ} 18^{\prime} \mathrm{S}$, longitude: $56^{\circ} 16^{\prime} \mathrm{W}$ and altitude of $82 \mathrm{~m}$ ). The local climate according to Köppen classification is category C, CFA subtype (Subtropical climate) without dry season (Wrege et al. 2011). The soil of the region is classified as Typic Regolithic (Embrapa, 2006).

The orchard was established in 2004, with the grapevine cultivars Marselan and Tannat grafted on 'Pausen 1103', conducted in espalier system, with spacing planting of $4 \mathrm{~m}$ between rows and $1.25 \mathrm{~m}$ between plants on the same row (2,000 plants ha-1), and used to summer pruning of topping type. In order to conduct the experiment plants were randomly chosen, using a completely randomized design with 5 replications, each plant considered one repetition.

The minimum and maximum daily air temperature data and rainfall during trial period and were collected at the weather station of the Universidade Federal do Pampa, Campus Itaqui (latitude 29 9'37 "S, longitude $56^{\circ} 33^{\prime} 19^{\prime} \mathrm{W}$, altitude of 82 meters), located at $32.24 \mathrm{~km}$ from the experiment. The daily thermal time (STd, ${ }^{\circ} \mathrm{C}$ day) were calculated according to Arnold (1960):

STd $=($ Tmed - Tb) day

wherein, the average daily air temperature (Tmed) was calculated using the arithmetic mean between the minimum (Tmin) and maximum daily air (Tmax) temperatures, and $\mathrm{Tb}$ is the base temperature for node emissions in grapevine, below which there is no emission of new foliar structures. In this study the adopted $\mathrm{Tb}$ was $10^{\circ} \mathrm{C}$ (Santos et al., 2011) and the accumulated thermal time $\left(\mathrm{STa},{ }^{\circ} \mathrm{C}\right.$ day), was calculated by the sum of STd $(\mathrm{STa}=\Sigma \mathrm{STd})$.

Every two weeks, from the early of sprouting, it was counted the number of visible nodes in each of branche of plant during the vegetative growth cycle of the crop. The plastochron was estimated by the inverse of the slope of the linear regression between the number of visible nodes by branches and accumulated thermal time (STa, ${ }^{\circ} \mathrm{C}$ day).

The average number of nodes per branches and plastochron, determined on the different cultivars, was subjected to analysis of variance and its means compared by Tukey test ( $p \leq 5 \%$ ), using the ASSISTAT statistical program 7.6 Beta version (Silva, 2013).

\section{Results and discussions}

According to rainfall data, minimum, maximum and average air temperatures obtained on observation periods of the studied culture (from October to December 2010) (Table 1), it is possible to observe that for minimum air temperature, values ranged from $12.6^{\circ} \mathrm{C}$ (September) and $19.8^{\circ} \mathrm{C}$ (December) for maximum air temperature between $21.2^{\circ} \mathrm{C}$ (September) and $31.2^{\circ} \mathrm{C}$ (December) for average air temperature, between $17.6{ }^{\circ} \mathrm{C}$ (September) and $25.2^{\circ} \mathrm{C}$ (December), and for the rainfall between $141.2 \mathrm{~mm}$ (October) and $551.2 \mathrm{~mm}$ (December).

Values of $26.8^{\circ} \mathrm{C}$ and $21.37^{\circ} \mathrm{C}$, respectively for medium temperature of means of maximum temperature and mean of average air during the months that comprises the experiment implementation period are desirable. Given that the air temperature interfere in photosynthetic activity and grapevine evapotranspiration process, as photosynthetic reactions are less intense under temperatures below $20^{\circ} \mathrm{C}$ due to the partial stomata closing occurring on maxi- 
mum activity (productivity) when temperature is between $25^{\circ} \mathrm{C}$ and $30^{\circ} \mathrm{C}$ (Teixeira et al., 2010).

The average daily thermal time (STdm) from the early of sprouting until the end vegetative cycle, that consisted of 85 days and it was $10.72{ }^{\circ} \mathrm{C}$ day,

Table 1 - Average monthly (Tm), minimum (Tmin) and maximum (Tmax) air temperature and accumulated rainfall during the estimate period used for plastochron.

\begin{tabular}{lcccc}
\hline Month & $\operatorname{Tmin}\left({ }^{\circ} \mathrm{C}\right)$ & $\operatorname{Tmax}\left({ }^{\circ} \mathrm{C}\right)$ & Tmed $\left({ }^{\circ} \mathrm{C}\right)$ & Rainfall $(\mathrm{mm})$ \\
\hline Setember & 12.5 & 21.2 & 17.6 & 240.4 \\
October & 14.0 & 26.4 & 19.8 & 141.2 \\
November & 15.9 & 28.5 & 22.7 & 263.2 \\
December & 19.8 & 31.2 & 25.2 & 551.2 \\
\hline Average & 15.5 & 26.8 & 21.3 & 299.0 \\
\hline SD & \pm 3.14 & \pm 4.23 & \pm 2.86 & \pm 152.66 \\
\hline
\end{tabular}
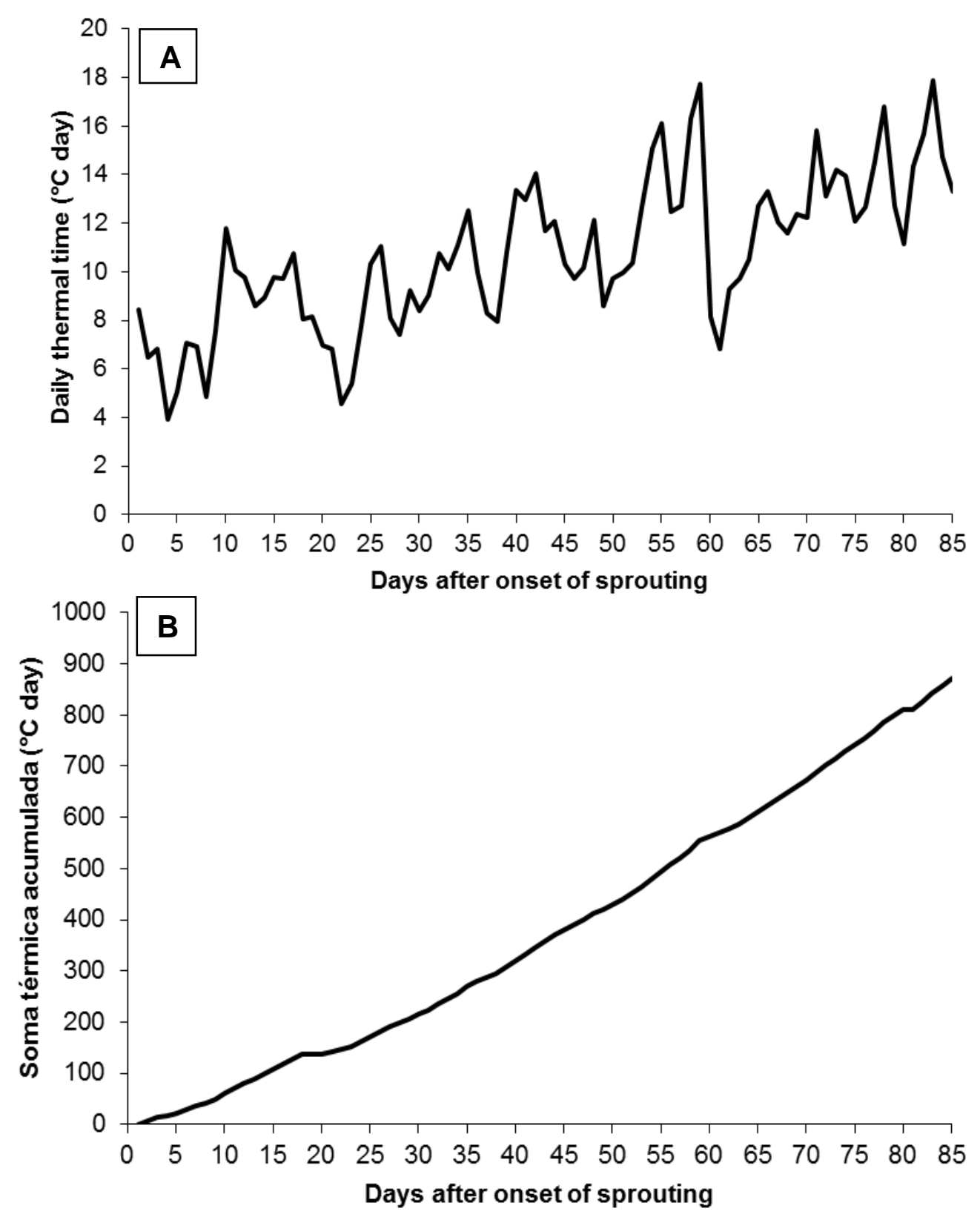

Figure 1 - Daily thermal time (STd) (A) and accumulated thermal time (STa) during the vegetative growing of grapevine (B), on September, October and December 2010. 
Through linear regression the relationship between the number of visible nodes per branches of Marsela and Tannat cultivars and thermal time (base temperatura of $10^{\circ} \mathrm{C}$ ) was obtained. There was close relationship $\left(R^{2} \geq 0.90\right)$ between the number of nodes (NN) per branches and accumulated thermal time ( ${ }^{\circ} \mathrm{C}$ day) for the evaluated Marselan and Tannat cultivars (Table 1 ). $R^{2}$ values superior to $\geq 0,90$, indicates the existence of linearity between NN and $\mathrm{STa}$, demonstrating that air temperature is the major environmental factor that governs the appearance of nodes in grapevine. What expressed that the estimate of leaf development with the estimate plastochron by linear regression method between NN and STa is an an appropriate methodology for the growing of grapevines. In Figure 3 can be observed examples of the equations obtained in the realization of the estimate plastochron for 'Marselan' (Figure 2) and 'Tannat' (Figure 2 B) grape cultivars.
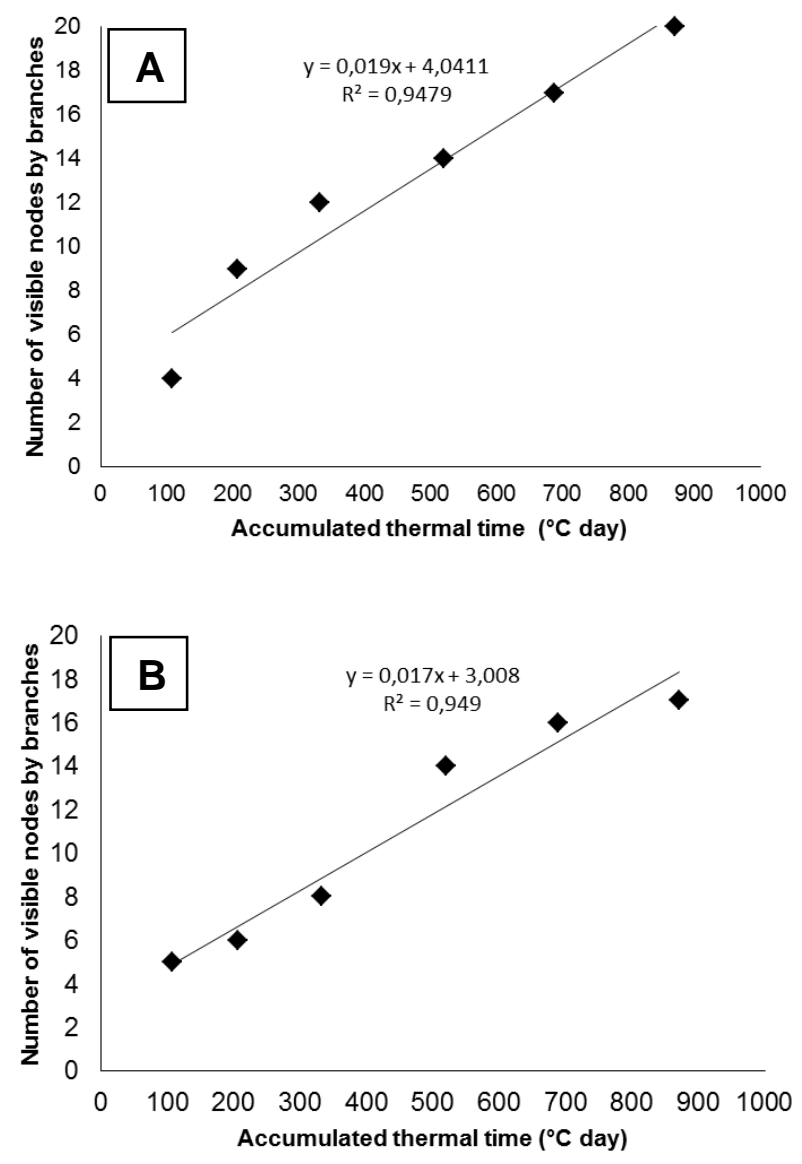

Figure 2 - Linear regressions between number of nodes (NN) visible on the main stem and the thermal time (STa) (base temperature of $10^{\circ} \mathrm{C}$ ) of one of the branches of the grapevine cultivars Marselan (Figure $2 \mathrm{~A}$ ) and Tannat (Figure $2 \mathrm{~B}$ ), used to estimate plastochron.

Cultivars showed similar values for the average number of branches per plant, average number of nodes per branches and estimate plastochron variables, with no significant differences
(Table 2). Being 56.8 and $55.7{ }^{\circ} \mathrm{C}$ day node ${ }^{-1}$, respectively the estimated plastochron for Marselan and Tannat grapevine cultivars.

Table 2 - Average number of branches per plant, average number of nodes per branches, coefficient of determination $\left(\mathrm{R}^{2}\right)$ and plastochron for different grapevine cultivars.

\begin{tabular}{llccl}
\hline Cultivar & Branches & Number of nodes & $\mathrm{R}^{2}$ & Plastochron \\
\hline Marselan & $8.4( \pm 0.89) \mathrm{a}$ & $19.9( \pm 0.95) \mathrm{a}$ & $0.90( \pm 0.01)$ & $56.8( \pm 7.62) \mathrm{a}$ \\
Tannat & $7.4( \pm 1.34) \mathrm{a}$ & $18.1( \pm 1.10) \mathrm{a}$ & $0.93( \pm 0.01)$ & $55.7( \pm 8.38) \mathrm{a}$ \\
\hline Average & $7.9( \pm 0.70)$ & $19.02( \pm 1.30)$ & $0.91( \pm 0.02)$ & $56.2( \pm 0.77)$ \\
\hline Means followed by the same letter in the column, not differ by Tukey test $(\mathrm{p} \leq 5 \%)$
\end{tabular}


Similar values of plastochron between different cultivars were also obtained in soybean by Martins et al. (2011), where estimated values for two crop seasons, did not differ from each other. The similarity of plastochron between grapevine cultivars, indicates that a single value for both plastochron for both cultivars may be used. What makes plastochron estimation model the most robust and easily applied (Streck et al., 2008).

In the method of degree-day, for plants complete its development cycle require a certain thermal time, in which only the amount of accumulated energy above the base temperature is favorable for vegetative development (Trentin et al., 2008). When no occurrence of abrupt changes in climate conditions, as excess or scarcity of rains and wide temperature variation, of a crop year to another, the thermal time works well to perform the management of agricultural crops. Based on that when the crop cycle occurs during the recommended period, where the temperature conditions are ideal for the development, temperatures fit the linear response range of vegetative growth to temperature (Streck et al., 2005).

The plant leaf area is directly associated with the number of nodes $(\mathrm{N})$ being responsible for the interception of solar radiation used in photosynthesis, which will influence production biomass by plant canopy (Fagundes et al., 2008), and consequently affects crop cycle duration (Streck et al., 2006), and it can be used as an indicator of productivity. With the correct application time of crop practices and proper management of plant canopy provides beyond maturity of berries, improved sensory quality of wines (Borghezan et al., 2011).

BY using the thermal time calculated to represent biological time in plants, it is possible to improve the prediction occurrence date of plants at development stages (Streck et al., 2005). The plastochron value information calculated for Marselan and Tannat grapevine cultivars $\left(56.25^{\circ} \mathrm{C}\right.$ day node $\left.{ }^{-1}\right)$, represent a possibility to stipulate the duration of the species development stages, predicting the early and suspension of vegetative growth according to the conditions of air temperature.

\section{Conclusions}

For Marselan and Tannat grapevine cultivars can be used the plastochron value of $56.25{ }^{\circ} \mathrm{C}$ day node $^{-1}$.

\section{References}

Baker JT, Reddy VR (2001) Temperature effects on phenological development and yield of muskmelon. Annals of Botany 87(1):605-613.

Borghezan M, Pit FA, Gavioli O, Malinovski LI, Silva AL (2011) Efeito da área foliar sobre a composição da uva e a qualidade sensorial dos vinhos da variedade Merlot (Vitis vinifera L.) cultivada em São Joaquim, SC, Brasil. Ciência e Técnica Vitivinícola 26(1):01-09.
Brixner GF, Martins CR, Amaral U, Köpp LM, Oliveira DB (2010) Caracterização fenológica e exigência térmica de videiras vitis vinifera, cultivadas no município de Uruguaiana, na Região da Fronteira Oeste RS. Revista da Faculdade de Zootecnia 17(2):221-233.

Embrapa - Empresa Brasileira De Pesquisa Agropecuária (2006) Centro Nacional de Pesquisa de Solos. Sistema brasileiro de classificação de solos. 2.ed. Rio de Janeiro, 306p.

Fagundes JD, Streck NA, Storck L, Reiniger LRS, Kruse ND (2008) Temperatura base, plastocrono e número final de nós no malmequer-do-campo. Ciência Rural 38(9):2471-2477.

FAO - Food and Agricultural Organization of the United Nations (2014) FAOSTAT data. Disponível em: <http://faostat.fao.org/faostat/servlet/>. Acesso em: 04 jan. 2014.

Heldwein AB, Streck NA, Sturza VS, Loose LH, Zanon AJ, Toebe M, Souza AT, Peters MB, Karlec F (2010) Plastocrono e rendimento de feijão-de-vagem cultivado sob ambiente protegido e no ambiente externo em semeadura tardia no outono. Ciência Rural 40(4):768-773.

IBGE - Instituto Brasileiro de Geografia e Estatística) (2014) Censo demográfico de 2010. Rio de Janeiro.

Liu B, Heins D (2002) Photothermal ratio affects plant quality in 'Freedom' Poinsettia. Journal of the American Society for Horticultural Science 127(1):20-20.

Lucas DDP, Streck NA, Bortoluzzi MP, Trentin R, Maldaner IC (2012) Temperatura base para emissão de nós e plastocrono de plantas de melancia. Revista Ciência Agronômica 43(2):288-292.

Martins JD, Radons SZ, Streck NA, Knies AE, Carlesso R (2011) Plastocrono e número final de nós de cultivares de soja em função da época de semeadura. Ciência Rural 41(6):954-959.

Muccillo L, Gambuti A, Frusciante L, lorizzo M, Moio L, Raieta K, Rinaldi A, Colantuoni V, Aversano R (2014) Biochemical features of native red wines and genetic diversity of the corresponding grape varieties from Campania region. Food Chemistry 143:506-513.

Pereira LC, Campelo Júnior JH, Ferronato A (2010) Comparação de métodos para estimativa do plastocrono em algodoeiro em condições tropicais. Pesquisa Agropecuária Tropical 40(2):213-220.

Santos AO, Hernandes JL, Pedro Junior MJ, Pereira SE (2011) Composição da produção e qualidade da uva em videira cultivada sob dupla poda e regime microclimático estacional contrastante. Revista Brasileira de Fruticultura 33(4):1135-1154. 
Silva FAS (2013) ASSISTAT: Versão 7.6 beta. DEAGCTRN-UFCG - Atualizado em 05 de maio de 2013. Disponível em <http://www.assistat.com/>. Acesso em: 20 de maio de 2013.

Silva RP, Dantas GG, Naves RV, Cunha MG (2006) Comportamento fenológico de videira, cultivar Patrícia, em diferentes épocas de poda de frutificação em Goiás. Bragantia 65(3):399-406.

Streck NA, Bosco LC, Michelon S, Walter LC, Marcolin E (2006) Duração do ciclo de desenvolvimento de cultivares de arroz em função da emissão de folhas no colmo principal. Ciência Rural 36(4):1086-1093.

Streck NA, Paula GM, Camera C, Menezes NL, Lago I (2008) Estimativa do plastocrono em cultivares de soja. Bragantia 67(1):67-73.

Streck NA, Tibola T, Lago I, Buriol GA, Heldwein AB, Schneider FM, Zago V (2005) Estimativa do plastocrono em meloeiro (Cucumis melo L.) cultivado em estufa plástica em diferentes épocas do ano. Ciência Rural 35(6):1275-1280.
Teixeira AHC, Moura MSB, Angelotti F (2010) Aspectos agrometeorológicos da cultura da videira. In: Moreira NA, Paranhos BJ, Faria CMB (Ed.). Cultivo da Videira. Petrolina: Embrapa Semiárido. (Sistemas de Produção, 1 - 2a . edição). Disponível em: <http://sistemasdeproducao.cnptia.embrapa.br/Fontes HTML/Uva/CultivodaVideira_2ed/clima.html>. Acesso em: 10 jan. 2014.

Toebe M, Lopes SJ, Storck L, Silveira TR, Milani M (2010) Casarotto. Estimativa de plastocrono em crambe. Ciência Rural 40(4):793-799.

Trentin R, Schreiber F, Streck NA, Buriol GA (2008) Soma térmica de subperíodos do desenvolvimento da planta de melancia. Ciência Rural 38(9): 24642470.

Wrege MS, Steinmetz S, Reisser Junior C, Almeida IR (2011) Atlas climático da Região Sul do Brasil: Estados do Paraná, Santa Catarina e Rio Grande do Sul. 1. Pelotas: Embrapa Clima Temperado, Colombo: Embrapa Florestas. 336p. 